\title{
Modeling Bat Species Richness and Spatial Distribution in Burkina Faso
}

\section{Napoko Malika Kangoyé*, Adama Oueda, Rimwaodo Pierre Silga, Idrissa Ouedraogo, Wendengoudi Guenda, Boureima Gustave Kabre}

Life and Earth Sciences Training and Research Unit, University Joseph Ki-Zerbo, Ouagadougou, Burkina Faso

Email: *kangoyemalika@yahoo.fr

How to cite this paper: Kangoyé, N.M., Oueda, A., Silga, R.P., Ouedraogo, I., Guenda, W. and Kabre, B.G. (2021) Modeling Bat Species Richness and Spatial Distribution in Burkina Faso. Open Journal of Ecology, 11, 790-806.

https://doi.org/10.4236/oje.2021.1111048

Received: September 29, 2021

Accepted: November 9, 2021

Published: November 12, 2021

Copyright (c) 2021 by author(s) and Scientific Research Publishing Inc.

This work is licensed under the Creative

Commons Attribution International

License (CC BY 4.0).

http://creativecommons.org/licenses/by/4.0/

Open Access

\begin{abstract}
The spatial distribution of bats in Burkina Faso is little-known. Previous studies have only described the bat species' richness in Burkina Faso. This study was conducted to highlight bat species' richness distribution within Burkina Faso and environmental variables that influence this distribution with the aim to give support for protection and further sampling for biodiversity. The Species Distribution Models (SDMs) were used to perform this study. To do that, species occurrences were collected throughout literature and field sampling and correlated to environmental variables through the Maxent software (Maximum Entropy). Our modeling variables included climate, vegetation cover, topography and hydrography data. The Jackknife test was performed to determine the importance of environmental variables that influence the species distribution model. The results showed that bats are present in all areas of vegetation in Burkina Faso. Species richness varies across the country. The species richness for major families increases from North to South. The total annual precipitation and topography are the main variables that positively influence bats distribution in Burkina Faso but the bare ground cover and standard deviation of the maximum temperature negatively influence this distribution. This modeling approach of bat species richness is important for policies makers and represents an invaluable tool in ecological management, particularly in the current context of climate change.
\end{abstract}

\section{Keywords}

Bats, Distribution Species Model, Richness, Maxent, Burkina Faso

\section{Introduction}

Bats are one of the most ecologically diverse groups of vertebrates. They belong 
to the order of Chiroptera, which has a wide variety of species. It is the second largest group of mammals after rodents. Currently, there are 1.300 bat species described worldwide; this represents about a quarter of known mammals [1]. Bats are considered keystone species in maintaining ecosystem functions [2] [3] [4] [5]. Some bat species are used by local people in their dietary as protein complement and others are useful in medicine [6] [7] [8]. They are also considered as hosts of some parasites which can cause many diseases for human being. Indeed, there are some negative perceptions associated with their zoonotic potential [9] [10] [11]. Some authors argued that the loss of bats could increase human reliance on chemical pesticides, jeopardize ecosystems and harm human economies [12] [13].

Despite the important ecological role of bats worldwide, they are often neglected and few studies have interested in them especially in Africa. As a result, our knowledge of these species is very limited and therefore, does not allow us to protect them and exploit the ecosystem services they can provide. Till the first mention about bats from Burkina Faso in 1969 [14] little is known about these mammals. Nevertheless, important insight given till 2012 [15], based on a large sampling area in 32 localities described 45 species with 15 new records [16] and [17] respectively described the distribution of species and the population's structure in Burkina Faso. It has been demonstrated that environmental variables influence bat species' spatial distribution. An adequate understanding of their ecology and distribution area is important in the development and implementation of policy and management actions that are crucial to the long-term survival of these species, especially in Burkina Faso. In the current context of terrorism in Burkina Faso supported by the Covid-19 pandemic, it is becoming increasingly difficult to explore certain sites for biodiversity inventory. Fortunately, Species Distribution Models (SDMs) demonstrated their utility to predict species' fundamental niche. So, this study was conducted using SDMs to predict bat species richness throughout Burkina Faso to answer three main questions. 1) Is the hotspot of predicted bat diversity corresponding to the protected areas in Burkina Faso? 2) Are they some areas where additional sampling effort can provide more species? 3) What are the main bioclimatic variables that govern the spatial distribution of bat species in Burkina Faso? Addressing these questions, will be of high importance for a) Supporting bats conservation policies; b) Identifying further sampling areas; c) Monitoring biodiversity specifically in this context emerging zoonotic diseases like Covid-19.

\section{Methodology}

\subsection{Study Area}

This study covers the entire area of Burkina Faso, a landlocked Sahelian country located in West Africa with an area of 274,200 $\mathrm{km}^{2}$. Most (about 75\%) of its territory is based on a Precambrian crystalline basement which gives it a generally flat relief [18]. Burkina Faso's hydrographic network is enough relatively dense 
despite the precarious weather conditions. The country is characterized by a Sudano-Sahelian tropical climate, in general, with two seasons: the dry season from October to April and the rainy season from May to September. The larger part of the country is located in the Sudanian climatic zone, including the Center and the South. The northern part of the country is influenced by Sahelian climate [19]. Guinko [20] and Fontès and Guinko [21] distinguish two large phytogeographical areas on the basis of climate, vegetation and fauna; the Sahelian and Sudanian areas, each being divided into two sectors. The vegetation of the Sahelian phytogeographical area includes shrub and tree steppes, grassy steppes, contracted training (tiger bush), riparian and riverine cords formations [22]. The Sudanian phytogeographical area locates south of the thirteenth parallel. The vegetation is characterized by a set of savannas (from woodland to grassland).

\subsection{Data Collection}

The occurrences (geographical coordinates of localities where the species were observed) and environmental variables are the two types of data used for the SDM. Occurrences used come from a literature review (covering the period of 1964 to 2008) and a field collection from 2009 to 2012. They cover all the national territory (Figure 1). Environmental variables including climate data, topography, land cover and hydrography were collected from various sources (Table 1). Climate data were downloaded from WORLDCLIM version 1.4 [23], land cover data derived from MODIS Vegetation Continuous Fields $[=\mathrm{VCF}]$ collection 3 [24] and SPOT VGT mosaic Africa data 2000 [25]. Topography data come

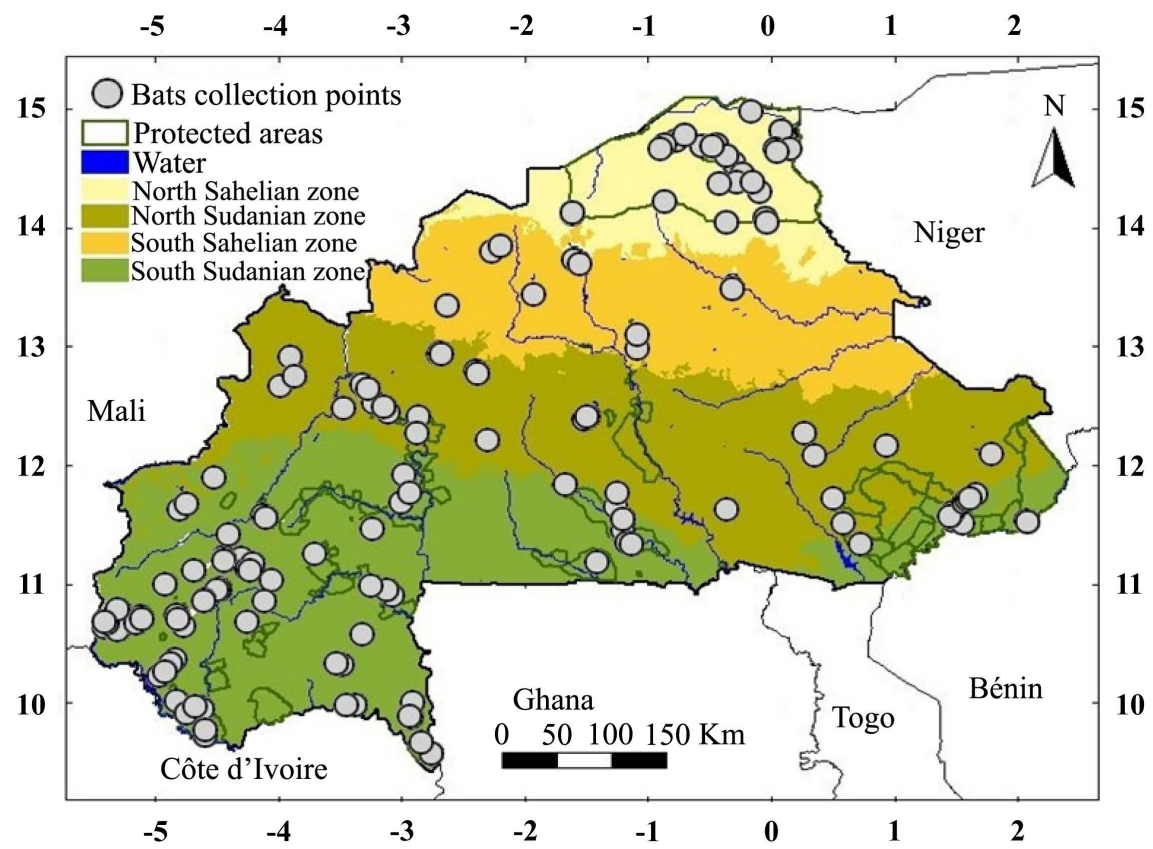

Figure 1. Map of Burkina Faso showing the vegetation zones and the bats collection points. 
Table 1. List of environmental variables.

\begin{tabular}{|c|c|c|c|}
\hline Abbreviation & Variables description & Sources & $\begin{array}{l}\text { Original } \\
\text { resolution }\end{array}$ \\
\hline srtm-c-ln- $3 * 3$ & Altitude & NASA & $1 \mathrm{~km}$ \\
\hline srtm-v-ln-9*9 & Altitude & NASA & $1 \mathrm{~km}$ \\
\hline prec_30_max & $\begin{array}{l}\text { Maximum value } \\
\text { ("wettest month") of the } \\
12 \text { monthly precipitation }\end{array}$ & WorldClim 1.4 & $1 \mathrm{~km}$ \\
\hline prec_30_min & $\begin{array}{l}\text { Minimum value } \\
\text { ("driest month") of the } \\
12 \text { monthly precipitation }\end{array}$ & WorldClim 1.4 & $1 \mathrm{~km}$ \\
\hline prec_30_std & $\begin{array}{l}\text { Standard deviation of the } \\
12 \text { monthly precipitation data }\end{array}$ & WorldClim 1.4 & $1 \mathrm{~km}$ \\
\hline prec_30_sum & $\begin{array}{l}\text { Total annual precipitation } \\
\text { calculated as the sum of } \\
\text { all } 12 \text { monthly rainfall }\end{array}$ & WorldClim 1.4 & $1 \mathrm{~km}$ \\
\hline tmax30_max & $\begin{array}{l}\text { Maximum of the mean } \\
\text { monthly maximum temperature }\end{array}$ & WorldClim 1.4 & $1 \mathrm{~km}$ \\
\hline tmax30_min & $\begin{array}{l}\text { Minimum of the mean } \\
\text { monthly maximum temperature }\end{array}$ & WorldClim 1.4 & $1 \mathrm{~km}$ \\
\hline tmax30_std & $\begin{array}{l}\text { Standard deviation of the } \\
\text { mean monthly } \\
\text { maximum temperature }\end{array}$ & WorldClim 1.4 & $1 \mathrm{~km}$ \\
\hline tmin30_max & $\begin{array}{l}\text { Maximum of the mean } \\
\text { monthly } \\
\text { minimum temperature }\end{array}$ & WorldClim 1.4 & $1 \mathrm{~km}$ \\
\hline tmin30_min & $\begin{array}{l}\text { Minimum of the } \\
\text { mean monthly } \\
\text { minimum temperature }\end{array}$ & WorldClim 1.4 & $1 \mathrm{~km}$ \\
\hline tmin30_std & $\begin{array}{l}\text { Standard deviation of } \\
\text { the mean monthly } \\
\text { minimum temperature }\end{array}$ & WorldClim 1.4 & $1 \mathrm{~km}$ \\
\hline glc_raw2 & $\begin{array}{l}\text { Annual average of spectral } \\
\text { response values in the } \\
\text { Near-Infrared, band } 2\end{array}$ & $\begin{array}{l}\text { SPOT-VEGETATION } \\
\text { composite }\end{array}$ & - \\
\hline glc_raw3 & $\begin{array}{l}\text { Annual average of spectral } \\
\text { response values in the } \\
\text { Red channel, band3 }\end{array}$ & $\begin{array}{l}\text { SPOT-VEGETATION } \\
\text { composite }\end{array}$ & - \\
\hline bare & Percent of bare ground cover & MODIS & $500 \mathrm{~m}$ \\
\hline herb & $\begin{array}{l}\text { Percent of herbaceous } \\
\text { ground cover }\end{array}$ & MODIS & $500 \mathrm{~m}$ \\
\hline tree & Percent of tree ground cover & MODIS & $500 \mathrm{~m}$ \\
\hline hydro_buff_af & Proximity to water bodies & DCW data & $1 \mathrm{~km}$ \\
\hline
\end{tabular}


from Shuttle Radar Topography Mission (SRTM) [26]. Data on the river system from the Geographic Information System for Burkina Faso (BF GIS) developed within the framework of the project "SFB 268-History of cultures and languages in the natural area of the African Savannah" to the Institute of Physical Geography of the Johann Wolfgang Goethe University in Frankfurt am Main.

\subsection{Modeling Approach}

The maximum entropy theory was used through the Maxent software version 3.4.0 for the SDM. Maxent is a general method based on statistical analysis to predict the best environmental conditions for species, from environmental variables and species occurrence. We applied MaxEnt's default function with 10 replicate cross-validation. Jackknife test was also applied to evaluate the variable importance. To create the Species Richness Distribution (SRD) we first created individual SDM from all the 44 species which present each at least two occurrences. For each individual SDM, eighteen environmental variables were used because of their ecological importance in bats distribution. These are ten from climate variables, five from vegetation cover, two from topography and one from hydrography (Table 1). The spatial resolution was harmonized to 30 arc seconds in order to have a high resolution which is necessary to give best information per grid cell.

The species occurrence data were organized as follows: the national territory has been divided into a grid of approximately 1 kilometer. In cases where we had several records in the same grid, we chose the best records taking into account the quality of the coordinates (taken with a GPS or not), the reliability of the species identification (qualification of the identifier) and the age of the data (old or recent). After using that, if there are still cells with more than one record, we choose one of them by centering it in the grid. Then, records that have not been selected for the training will be used as test points. For species with less than ten records, all records were used for training (Table 2).

Maxent was set up to perform 10 replicates and their average value was used to make the modeling. Area Under the Curve (AUC) was determined for model evaluation and was interpreted following [27]. In order to determine the predictive power of each environmental variable considered in the distribution of species and to identify those that contribute most to the model, the Jackknife test was also performed.

Individual models (by species) obtained with MaxEnt were then imported into $\mathrm{R}$ software version 4.0.2 to generate discrete distribution maps for each species as the Maxent output consists of a continuous probability map (from 0 to 1 ). The division is made from the smallest of the following three probability thresholds obtained with Maxent: the "10 percentile training presence", the "Equal training sensitivity and specificity" and the "Maximum training sensitivity plus specificity". Then, the discrete maps for species are added to give the SRD by family, and the overall SRD for the country by using R software version 4.0.2 with package "raster", "sp" and "rgdal". 
Table 2. List of bat species and the number of used records.

\begin{tabular}{|c|c|c|c|}
\hline Family & Species & $\begin{array}{c}\text { Records } \\
\text { for } \\
\text { training }\end{array}$ & $\begin{array}{c}\text { Records } \\
\text { for } \\
\text { test }\end{array}$ \\
\hline \multirow{7}{*}{ Pteropodidae } & Eidolon helvum (Kerr, 1792) & 14 & 0 \\
\hline & Epomophorus gambianus (Ogilby, 1835) & 49 & 41 \\
\hline & Hypsignathus monstrosus $\mathrm{H}$. Allen, 1862 & 3 & 0 \\
\hline & Myonycteris angolensis (Bocage, 1898) & 12 & 0 \\
\hline & Micropteropus pusillus (Peters, 1868) & 25 & 27 \\
\hline & Nanonycteris veldkampii (Jentink, 1888) & 13 & 12 \\
\hline & $\begin{array}{l}\text { Rousettus aegyptiacus } \\
\text { (E. Geoffroy St.-Hilaire, 1810) }\end{array}$ & 2 & 0 \\
\hline \multirow{7}{*}{ Hipposideridae } & Asellia tridens (E. Geoffroy St.-Hilaire, 1813) & 2 & 0 \\
\hline & Hipposideros abae J.A. Allen, 1917 & 9 & 0 \\
\hline & Doryrhina cyclops (Temminck, 1853) & 2 & 0 \\
\hline & Hipposideros jonesi Hayman, 1947 & 9 & 0 \\
\hline & Hipposideros ruber (Noack, 1893) & 28 & 8 \\
\hline & Hipposideros tephrus Cabrera, 1906 & 10 & 0 \\
\hline & Macronycteris vittatus (Peters, 1852) & 7 & 0 \\
\hline Megadermatidae & Lavia frons (E. Geoffroy St.-Hilaire, 1810) & 7 & 0 \\
\hline \multirow{3}{*}{ Rhinolophidae } & Rhinolophus alcyone Temminck, 1853 & 4 & 0 \\
\hline & Rhinolophus fumigatus Rüppell, 1842 & 13 & 4 \\
\hline & Rhinolophus landeri Martin, 1838 & 14 & 0 \\
\hline \multirow{2}{*}{ Rhinopomatidae } & Rhinopoma cystops Thomas, 1903 & 5 & 0 \\
\hline & Rhinopoma microphyllum (Brünnich, 1782) & 2 & 0 \\
\hline \multirow[b]{2}{*}{ Emballonuridae } & Taphozous nudiventris Cretzschmar, 1830 & 6 & 0 \\
\hline & $\begin{array}{l}\text { Taphozous perforatus } \\
\text { E. Geoffroy St.-Hilaire, } 1818\end{array}$ & 10 & 0 \\
\hline \multirow{4}{*}{ Nycteridae } & Nycteris gambiensis (K. Andersen, 1912) & 10 & 0 \\
\hline & Nycteris hispida (Schreber, 1774) & 23 & 4 \\
\hline & Nycteris macrotis Dobson, 1876 & 23 & 5 \\
\hline & Nycteris thebaica E. Geoffroy St.-Hilaire, 1818 & 9 & 0 \\
\hline \multirow{6}{*}{ Molossidae } & Mops condylurus (A. Smith, 1833) & 4 & 0 \\
\hline & Mops demonstrator (Thomas, 1903) & 3 & 0 \\
\hline & Mops major (Trouessart, 1897) & 11 & 0 \\
\hline & Mops midas (Sundevall, 1843) & 2 & 0 \\
\hline & Mops nigeriae (Thomas, 1913) & 4 & 0 \\
\hline & Mops pumilus (Cretzschmar, 1826) & 20 & 2 \\
\hline
\end{tabular}




\begin{tabular}{llll} 
Continued & & & \\
\hline & Myotis bocagii (Peters, 1870) & 2 & 0 \\
& Laephotis guineensis (Bocage, 1889) & 26 & 4 \\
Laephotis nanus (Peters, 1852) & 6 & 0 \\
& Neoromicia somalica (Thomas, 1901) & 13 & 0 \\
& Nycticeinops schlieffenii (Peters, 1859) & 20 & 7 \\
Pipistrellus inexspectatus Aellen, 1959 & 2 & 0 \\
Vespertilionidae & Pipistrellus rusticus (Tomes, 1861) & 5 & 1 \\
& Scotoecus albofuscus (Thomas, 1890) & 3 & 0 \\
& Scotoecus hirundo (de Winton, 1899) & 3 & 0 \\
& Scotophilus dinganii (A. Smith, 1833) & 2 & 0 \\
Scotophilus leucogaster(Cretzschmar, 1826) & 30 & 13 \\
Scotophilus viridis (Peters, 1852) & 16 & 9 \\
\hline
\end{tabular}

For each species, Maxent gives the contribution of each environmental variable to the SDM. We, therefore, estimated the weight of each environmental variable in the SRD by averaging the contributions of each variable by family and for the entire bat community. The synoptic figure below (Figure 2) shows the main steps of the modeling process.

\section{Results}

\subsection{Distribution of Bat Species Richness by Families and Model Quality}

The MaxEnt model had a moderately high performance by presenting medium value of 0.875 and 0.854 respectively for the training data and testing data (Figure 3). The AUC values obtained in this study varied from 0.638 for Mops major to 1.00 for Rousettus aegyptiacus and Doryrhina cyclops. These values of AUC indicate that the SDMs we generated achieved good levels for prediction.

Based on the available occurrence data, we modeled the distribution of 44 of the 51 bat species encountered. Modeled species belong to 9 families. SRD for those families are shown in Figure 4 and the means of environmental variables contribute to the SDM are presented in Table 3. Species richness of Pteropodidae, Hipposideridae, Molossidae, Nycteridae, Rhinolophidae and Vespertilionidae shows clear increases from north to south.

The distributions of Pteropodidae, Hipposideridae, Molossidae, Nycteridae, Rhinolophidae and Vespertilionidae follow clearly the climatic areas with higher richness in the Sudanian region. Pteropodidae reach the maximum richness in the hilly region in the extreme south-west part of the country. Then, maximum precipitation and topography are the two main variables that contribute most to the distribution of this family. The richness of Pteropodidae varies in the 


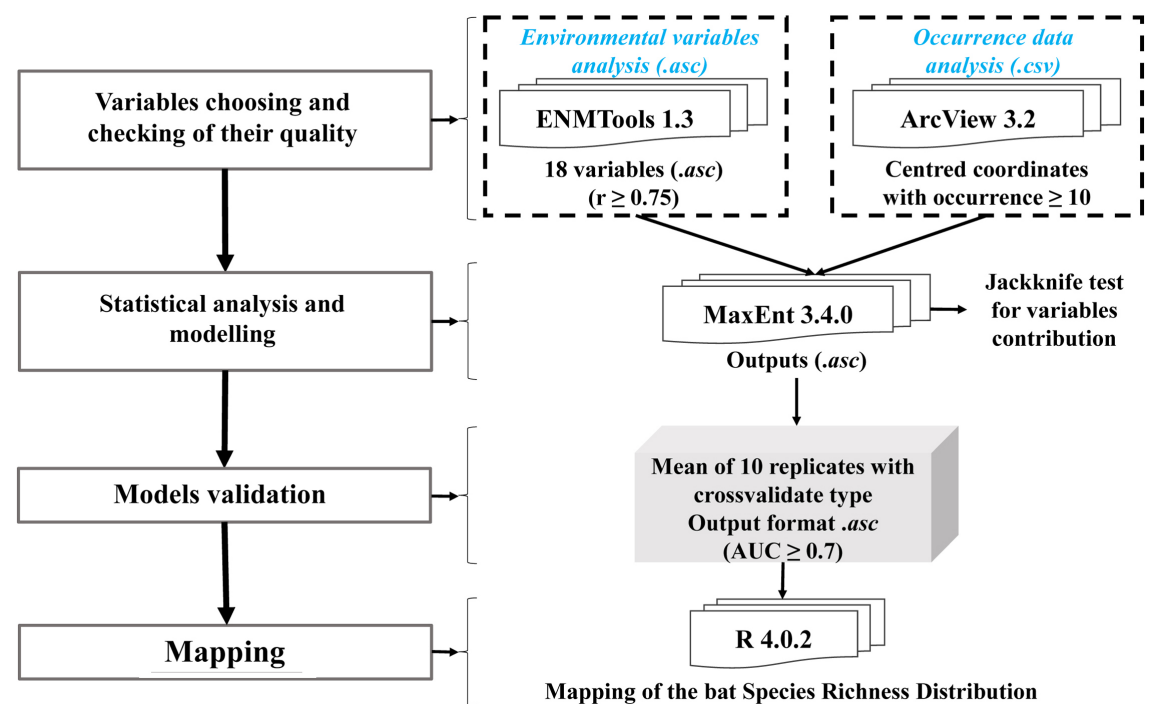

Figure 2. Illustration describing the scope of species richness modeling.

Table 3. Mean of environmental variables contribute to the SDM by family and for the chiropteran community in Burkina Faso. PT: Pteropodidae; EM: Emballonuridae; HI: Hipposideridae; ME: Megadermatidae; MO: Molossidae; NY: Nycteridae; RHL: Rhinolophidae; RHP: Rhinopomatidae; VE: Vespertilionidae; All: All Chiropterans.

\begin{tabular}{|c|c|c|c|c|c|c|c|c|c|c|}
\hline & $\mathrm{PT}$ & EM & $\mathrm{HI}$ & ME & MO & NY & RHL & RHP & VE & All \\
\hline$[\operatorname{tmin} 30-\min ]$ & 0.7 & 50.0 & 1.9 & 0.0 & 0.8 & 0.0 & 0.0 & 0.0 & 8.8 & 5.2 \\
\hline$[\operatorname{tmin} 30-\max ]$ & 0.0 & 0.3 & 0.0 & 0.0 & 0.0 & 0.0 & 0.0 & 5.5 & 0.0 & 0.3 \\
\hline [tmin $30-s t d]$ & 0.1 & 3.1 & 0.9 & 24.7 & 0.4 & 0.0 & 0.0 & 0.0 & 15.1 & 5.0 \\
\hline$[\operatorname{tmax} 30-\min ]$ & 0.7 & 0.0 & 0.8 & 0.0 & 19.6 & 0.0 & 0.0 & 0.0 & 0.1 & 2.9 \\
\hline$[\operatorname{tmax} 30-\max ]$ & 0.1 & 0.0 & 13.3 & 0.0 & 0.6 & 1.4 & 1.8 & 0.0 & 0.5 & 2.6 \\
\hline [tmax30-std] & 17.6 & 0.0 & 7.7 & 0.0 & 5.8 & 0.8 & 39.6 & 0.0 & 6.6 & 9.4 \\
\hline [prec30-min] & 1.1 & 46.7 & 3.7 & 0.0 & 23.8 & 10.9 & 1.6 & 0.0 & 6.0 & 8.9 \\
\hline [prec30-max] & 23.4 & 0.0 & 0.2 & 0.0 & 2.9 & 33.1 & 10.1 & 0.0 & 0.0 & 7.8 \\
\hline [prec30-std] & 2.1 & 0.0 & 18.1 & 0.0 & 0.8 & 0.0 & 27.6 & 10.1 & 0.0 & 5.7 \\
\hline [prec30-sum] & 4.2 & 0.0 & 16.5 & 0.0 & 2.0 & 1.6 & 10.7 & 3.8 & 20.6 & 10.2 \\
\hline$[$ tree $-4 * 4]$ & 13.0 & 0.0 & 3.1 & 0.0 & 0.0 & 22.7 & 0.0 & 0.1 & 4.5 & 5.8 \\
\hline$[$ herb $-4 * 4]$ & 0.4 & 0.0 & 2.8 & 0.0 & 1.1 & 0.0 & 0.0 & 0.0 & 0.3 & 0.7 \\
\hline$[$ bare $-4 * 4]$ & 10.4 & 0.0 & 12.1 & 75.3 & 20.7 & 0.1 & 0.2 & 0.0 & 5.6 & 9.6 \\
\hline [glc-raw2] & 0.6 & 0.0 & 0.2 & 0.0 & 6.4 & 0.1 & 0.3 & 20.5 & 0.0 & 2.0 \\
\hline [glc-raw3] & 2.2 & 0.0 & 0.0 & 0.0 & 0.1 & 0.0 & 0.0 & 0.0 & 9.9 & 3.0 \\
\hline$[\mathrm{srtm}-\mathrm{c}-\ln -3 * 3]$ & 0.7 & 0.0 & 0.2 & 0.0 & 1.1 & 0.5 & 0.3 & 2.8 & 13.9 & 4.3 \\
\hline$[$ srtm-v-ln $-9 * 9]$ & 22.4 & 0.0 & 14.9 & 0.0 & 1.2 & 0.0 & 7.6 & 52.6 & 2.8 & 9.8 \\
\hline [hydro_buff_af] & 0.6 & 0.0 & 3.7 & 0.0 & 12.7 & 28.9 & 0.4 & 4.8 & 5.5 & 6.8 \\
\hline
\end{tabular}




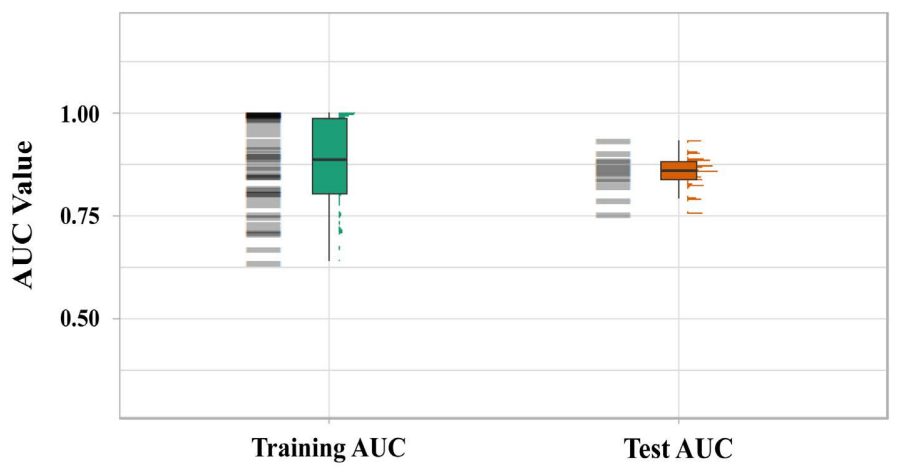

Figure 3. AUC value according to training and test.
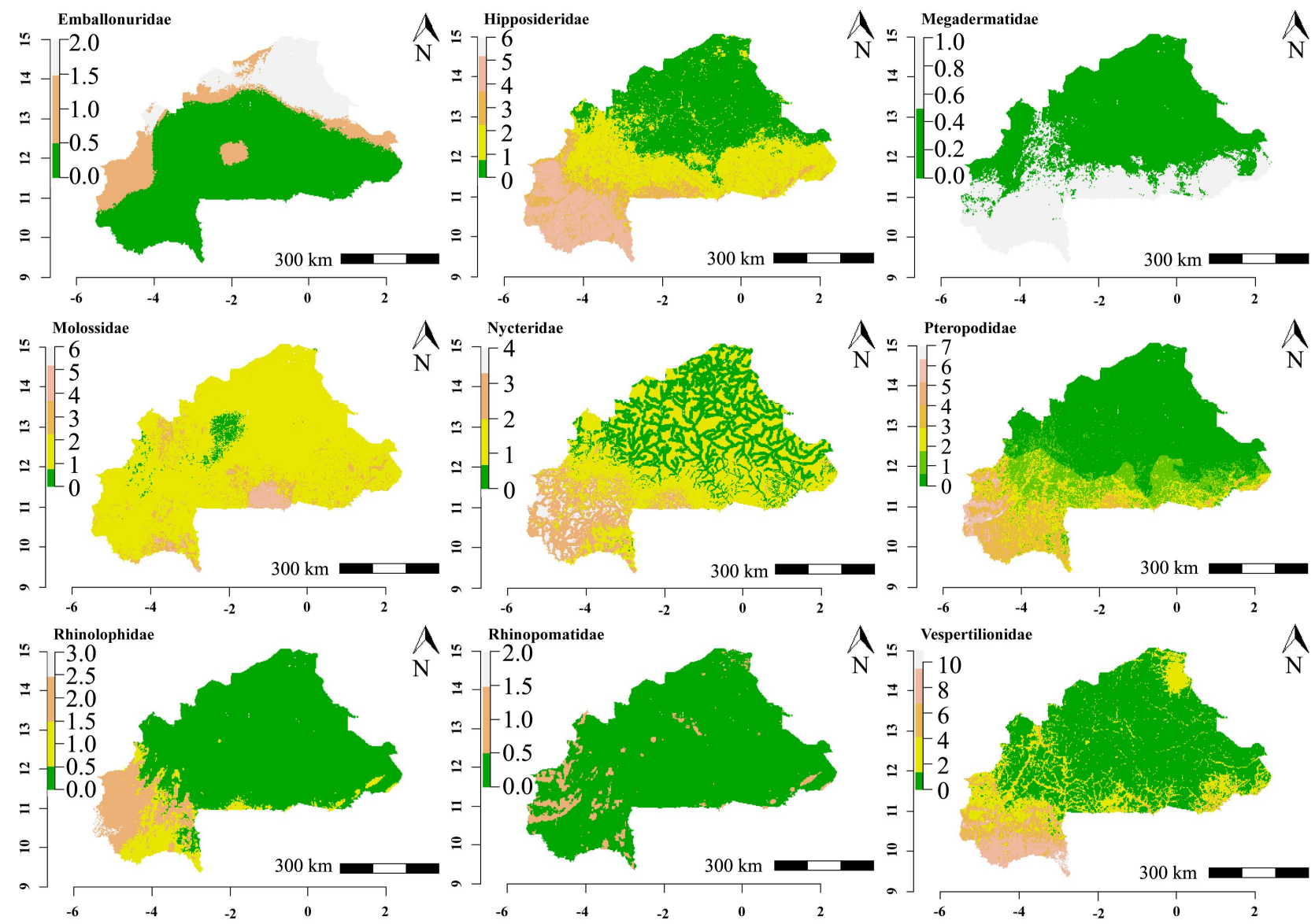

Figure 4. Maps of the bat species richness distribution by families.

same direction as the two variables, then these variables have a positive effect on the family richness. For Hipposideridae, the two most important variables, with positive correlation, are the standard deviation of precipitation and total annual precipitation. The highest richness in the south-west opposite to Pteropodidae doesn't correspond to the hilly region and covers up all of this area. Richness of Molossidae shows maximum in the follow the center of the South Sudanian area, in and around the protected area of Nazinga. Hydrography (rivers) are clearly important for this family in the Sahelian region. Minimum precipitation and 
bare ground cover are the two variables that contribute the most to their distribution. While bare ground cover shows a negative correlation, the minimum precipitation shows a positive correlation. Nycteridae presents the widest area for maximum richness, covering almost the Sudanian zone. In the Sahel region, the rivers play a positive and critical role lead to the presence of more species. But in the Sudanian Region Rivers are likely to decrease the number of species. Then, maximum precipitation and hydrography are shown to be the most important variables. Maximum precipitation shows a positive correlation with the Nycteridae diversity. The extreme south-west is a high diversity area for Rhinolophidae that are absent in the Sahelian regions. The standard deviation of maximum temperature and standard deviation of precipitation are the two main variables that contribute most to Rhinolophidae distribution. But, as distribution of Rhinolophidae shows opposite trend compared to the standard deviation of maximum temperature, we infer that this variable negatively influences their Rhinolophidae distribution. Vespertilionidae is the most diversified family in Burkina Faso, nearly present in all the country but with richness higher than 2 only in the Sudanian region. Highest richness (9 to 10 species) is found in the extreme south of the country at the border with Ghana and Cote d'Ivoire. Rivers are also an important element in the distribution of these species as they determine their presence in the Sahel and even in some parts of the Sudanian zone. Topography also seems an important factor in the extreme south-west, where part of the maximum wealth is observed. The two main environmental variables that contribute most to the distribution of Vespertilionidae are total annual precipitation and standard deviation of minimum temperature. Total annual precipitation shows a positive correlation and the standard deviation of minimum temperature shows a negative correlation to Vespertilionidae distribution.

In opposite to the previous families, Emballonuridae richness increases from south to north. The minimum of minimum temperature and minimum precipitation are the two main variables that contribute most to their distribution. These variables are negatively correlated to the Emballonuridae richness. Megadermatidae is a family with single species. Bare ground cover and standard deviation of minimum temperature are the two variables that contribute the most to this family distribution. These two variables show a negative correlation to the distribution of Megadermatidae family. Rhinopomatidae only present in the highest land of the country. Then topography and annual average of spectral response values in the Near-Infrared, band 2 (vegetation cover) are the two main variables that contribute most to their distribution. The topography therefore positively influences the distribution of Rhinopomatidae, unlike vegetation cover which negatively influences the distribution.

\subsection{Overall Pattern of Species Richness Distribution in Burkina Faso}

In Burkina Faso, bat species richness increases from north to south with a maximum richness in the hills of south-west region (Figure 5). The general pattern 


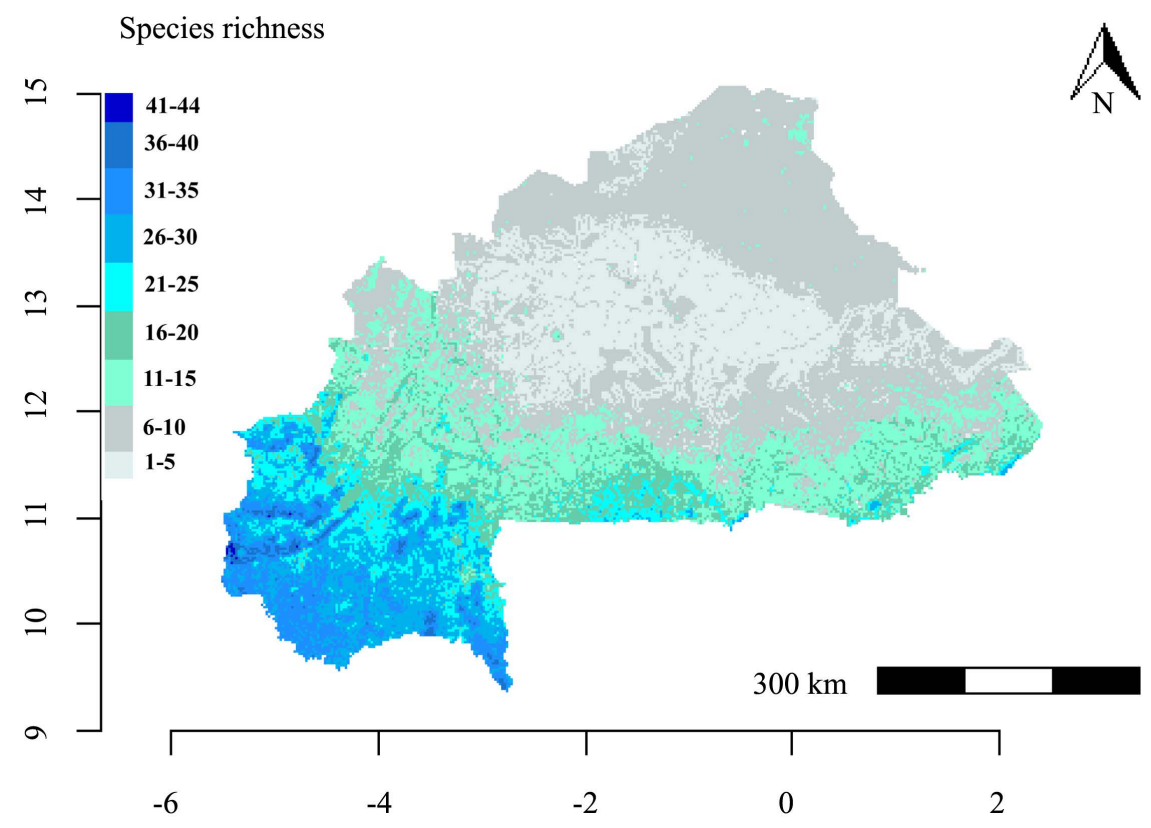

Figure 5. Bat species richness distribution in Burkina Faso.

shows that we can expect at least one species of bat anywhere in Burkina Faso. Changes in species richness superimpose perfectly to the climatic zones of Burkina Faso. By and large, in the Sahelian region, we can expect a maximum of 7 species with more species (from 6 to 15) following the river beds. The "bands" of richnes from 1 to 10 species, share the North-Sudanian zone while the "band" of 11 to 25 species lies troughout the South Sudanian region. The richnes of 26 to 44 species appear in the South Sudanian region, precisely at the most rugged sites in the country whose cliffs of Banfora and mountain ranges.

In order of importance, total annual precipitation, topography, bare ground cover and standard deviation of maximum temperature are the most contributing variables to the overall bats SRD in Burkina Faso (Table 3). Total annual precipitation and topography are positively correlected to bat species diversity while the bare ground cover and standard deviation of maximum temperature are negatively correlated to bat species diversity.

\section{Discussion}

\subsection{Model Quality and Variables That Govern Bat Species Richness in Burkina Faso}

The SDMs results showed a good performance of predicting models. Indeed, according to Araujo et al. [27], the results of SDMs are considered to be good when the AUC value is equal or more than 0.75. Bat species richness in Burkina Faso varies along the north-south gradient, with a positive correlation to the total annual precipitation and topography, the most important variables explaining the species distribution. As already shown, the diversity of bats increases with environmental heterogeneity and complexity of the habitat [28] [29]. Ac- 
cording to Tews et al. [30], the majority of studies show a positive correlation between habitat heterogeneity, as the horizontal development of vegetation [31], and diversity of animal species. Such habitat heterogeneity increase with the precipitation level that determines vegetation and the global weather and reaches its highest level in the south Sudanian regions of Burkina Faso. This also explains why the bare ground cover negatively influences bats' diversity, as this indicates less habitat heterogeneity. Indeed, from the North to the South of Burkina Faso, there is an increase in rainfall and therefore an improvement of the vegetation covers with the passage of shrub-steppe and wooded, grassy steppes to woodland to grassland [32]. This state is supported by the fact that some species as Eidolon helvum migrates annually into savannah regions along a north-south axis [11]. In addition, the South of Burkina Faso presents a set of specific habitats such as the many protected forests, galleries forest that increase the heterogeneity of environment. Seeing the habitat complexity as the vertical development of the vegetation [31], it is clear that habitats complexity reaches its highest level in the Sudanian regions, mainly in the extreme southwest, much richer, where humid Guinean flora appear along the main rivers [33]. We also note that in the Sahelian region of Burkina Faso, rivers contribute to increasing species richness. This is related to the fact that rivers, with their associate gallery forests, contribute to increasing habitat heterogeneity and complexity, thus offering specifically suitable habitats for some species. The rock formations like the cliffs of Banfora, Sindou peaks and the chain of Gobnangou increase habitat heterogeneity and complexity and offer additional lair for bats through many cracks and caves which are home and justify the weight of the topography in the determination of the bats' diversity. Large variations in the maximum temperature negatively affect the species richness of bats in Burkina Faso. This indicates the sensibility of bat fauna to the potential increase of temperatures and suggests a great vulnerability of these animals to global warming. In the same sense as this observation, Welbergen et al. [34] found that extreme temperatures are important threats to bats in Australia.

At the family level, three distribution patterns emerge. The diversity of Pteropodidae, Hipposideridae, Molossidae, Nycteridae, Rhinolophidae and Vespertilionidae follow the general trend increasing globally from North to South. Quite the reverse, the diversity of Emballonuridae decreases from North to South. The two species of this family (Taphozous nudiventris and $T$. perforatus) are all known from the north of the Sahara [35]. Then, we can suppose that the distribution area of these species is limited to the Sahelo-Saharian zone. The Rhinopomatidae family (Rhinopoma cystops and Rhinopoma microphyllum), although also present north of the Sahara [35], are strongly and positively related to the topography in Burkina Faso.

Although these variables show a good contribution to the models, we cannot assume that there are the only factors affecting bat diversity. Indeed, many studies like Hawkins et al. [36], Kalko [37] and Kalko [38] [39] showed that va- 
riables as the availability, abundance and distribution of food resources are also important factors that influence the organization and dynamics of bats.

\subsection{Hotspot of Bat Diversity and Protected Area in Burkina Faso}

The highest diversity of bats (from 36 to 44 species) appear in the most rugged area in the country with only narrow protected areas like the classified forests of Beregadougou, Denderesso and Koulima [40]. Sites like the cliffs of Banfora, the peaks of Sindou and the mountain range of Gobnangou where the highest diversity has been predicted are not officially protected sites. On the other hand, areas of good diversity (36 to 44 species), and that of fair diversity (16 to 20 species) are dotted with protected areas. This bodes well for optimal protection for the species found there. Thus, all the protected areas correspond fairly well to areas of high diversity of bat. Better, specific areas such as the Sahel reserve although located in an area of low diversity guarantee the heterogeneity and complexity of protected habitats. However, this complexity of protected habitats would benefit from being supplemented by the classification of larger areas of the Banfora cliffs, the Sindou peaks and the Gobnangou range.

\subsection{Importance of Additional Sampling Effort in Burkina Faso}

Kangoyé et al. [17] reported a specific richness of 1 to 12 species per sampling site after having compiled data from 164 sites visited over a period of 50 years in Burkina Faso. Similarly, Sawadogo [41] only encountered 11 species in the whole city of Ouagadougou. Several sites covered by these works have higher predicted specific richness levels. This suggests that it is possible to meet even more species there. Indeed, after having listed 51 species for Burkina Faso, Kangoyé et al. [17] using the rarefaction curves and the indices of Jackknife and Chao 2 and Boot underline that the total specific richness could reach 55 to 58 species. Thus, 4 to 7 species remain statistically likely to be encountered and the results of this work allow us to direct our future efforts towards areas of high heterogeneity and high complexity of habitats as well as towards protected areas. This is confirmed by the recent work of Thiombiano et al. [42] that recorded a new species (Taphozous mauritianus E. Geoffroy St.-Hilaire, 1818) in the city of Bobo-Dioulasso. The models of bats richness species produced in this study constitute a useful tool for their conservation management. Because of their economical and environmental benefits that they provide, conservation strategies should strive to maintain bat richness and their population.

\section{Conclusion}

This study employed species distribution modeling to determine the distribution of bat species richness in Burkina Faso. It shows that bats are everywhere in the country, with increasing diversity from north to south with the highest diversity in the hilly region of the south-west. Using the Jackknife test, we identified that variables as precipitations, topography, vegetation cover, and rivers bed are the 
principal determinant of the species richness distribution. Moreover, in the context of Burkina Faso diversity hotspot, mainly comprise the protected area. Hilly and rocky formations encountered in the southwest part of Burkina Faso host the largest bat diversity of the country and highlight the importance of this area in the conservation of biodiversity in Burkina Faso. In view of the ecological and therapeutic roles of bats already mentioned in the literature review and in view of their specific richness in Burkina Faso, it is obvious that the country has a great deal of biological wealth that should be preserved. Future studies could explore their multiple uses by local communities. This could contribute to their better sustainable management. This area of vital importance to bats of Burkina Faso should receive more attention from all stakeholder interested in the conservation and protection of biodiversity areas of important bats biodiversity like Banfora cliffs, the Sindou peaks, and the Gobnangou range need more protection measures. Finally, after 51 species further sampling effort in these areas and the other protected areas from the east and the south of Burkina Faso could mead to new records.

\section{Acknowledgements}

This article is dedicated to the memory of Professor Elisabeth K. V. Kalko. We thank Jacob Fahr for his support during this project. We are grateful to "BIOTA West Africa" funded this research.

\section{Conflicts of Interest}

The authors declare no conflicts of interest regarding the publication of this paper.

\section{References}

[1] Fenton, B. and Simmons, N. (2014) Bats: A World of Science and Mystery. University of Chicago Press, Chicago, $303 \mathrm{p}$.

[2] Hodgkison, R., Balding, S.T., Zubaid, A. and Kunz, T.H. (2003) Fruit Bats (Chiroptera: Pteropodidae) as Seed Dispersers and Pollinators in a Lowland Malaysian Rain Forest. Biotropica, 35, 491-502. https://doi.org/10.1111/j.1744-7429.2003.tb00606.x

[3] Gross-Camp, N.D., Mulindahabi, F. and Kaplin, B.A. (2009) Comparing the Dispersal of Large-Seeded Tree Species by Frugivore Assemblages in Tropical Montane Forest in Africa. Biotropica, 41, 442-451. https://doi.org/10.1111/j.1744-7429.2009.00511.x

[4] Kunz, T.H., Braun de Torrez, E., Bauer, D., Lobova, T. and Fleming, T.H. (2011) Ecosystem Services Provided by Bats. Annals of the New York Academy of Sciences, 1223, 1-38. https://doi.org/10.1111/j.1749-6632.2011.06004.x

[5] de la Peña-Domene, M., Martínez-Garza, C., Palmas-Pérez, S., Rivas-Alonso, E. and Howe, H.F. (2014) Roles of Birds and Bats in Early Tropical-Forest Restoration. PLoS ONE, 9, e104656. https://doi.org/10.1371/journal.pone.0104656

[6] Mickleburgh, S., Waylen, K. and Racey, P. (2009) Bats as Bushmeat: A Global Review. Oryx, 43, 217-234. https://doi.org/10.1017/S0030605308000938 
[7] Kamins, A.O., Restif, O., Ntiamoa-Baidu, Y., Suu-Ire, R., Hayman, D.T.S., Cunningham, A.A., Wood, J.L.N. and Rowcliffe, J.M. (2011) Uncovering the Fruit Bat Bushmeat Commodity Chain and the True Extent of Fruit Bat Hunting in Ghana, West Africa. Biological Conservation, 144, 3000-3008. https://doi.org/10.1016/j.biocon.2011.09.003

[8] Riccucci, M. (2012) Bats as Materia Medica: An Ethnomedical Review and Implications for Conservation. Vespertilio, 16, 249-270.

[9] Hayman, D.T.S., Suu-Ire, R., Breed, A.C., McEachern, J.A., Wang, L., Wood, J.L.N. and Cunningham, A.A. (2008) Evidence of Henipavirus Infection in West African Fruit Bats. PLoS ONE, 3, e2739. https://doi.org/10.1371/journal.pone.0002739

[10] Hayman, D.T.S., Yu, M., Crameri, G., Wang, L.-F., Suu-Ire, R., Wood, J.L.N. and Cunningham, A.A. (2012) Ebola Virus Antibodies in Fruit Bats, Ghana, West Africa. Emerging Infectious Diseases, 18, 1207-1209. https://doi.org/10.3201/eid1807.111654

[11] Abedi-Lartey, M. (2016) Quantifying the Ecological Impact of the Straw-Coloured Fruit Bat (Eidolon helvum) in West Africa. Ph.D. Thesis, Universität Konstanz, Faculty of Sciences, Department of Biology, Konstanz, 159 p.

[12] Ducummon, S.L. (2001) Ecological and Economic Importance of Bats. In: Vories, K.C. and Throgmorton, D., Eds., Proceedings of Bat Conservation and Mining. $A$ Technical Interactive Forum, US Department of Interior, Office of Surface Mining and Coal Research Center, Southern Illinois University, Carbondale.

[13] Kasso, M. and Balakrishnan, M. (2013) Ecological and Economic Importance of Bats (Order Chiroptera). International Scholarly Research Notices, 2013, Article ID: 187415. http://dx.doi.org/10.1155/2013/187415

[14] Kock, V.D. (1969) Die Fledermaus-Fauna des Sudan (Mammalia, Chiroptera). Kramer, Frankfurt, 238 p.

[15] Kangoyé, N.M., Oueda, A., Thiombiano, A. and Guenda, W. (2012) Bats (Chiroptera) of Burkina Faso: Preliminary List with Fifteen First Record Species. International Journal of Biological and Chemical Sciences, 6, 6017-6030.

http://dx.doi.org/10.4314/ijbcs.v6i6.29

[16] Kangoyé, N.M., Ouéda, A., Granjon, L., Thiombiano, A., Guenda, W. and Fahr, J. (2015) Diversity and Distribution of Bats (Mammalia, Chiroptera) in Burkina Faso. Biodiversity Journal, 6, 597-632.

[17] Kangoyé, N.M., Ouéda, A., Thiombiano, A. and Guenda, W. (2015) Diversité et structure du peuplement des chauves-souris au Burkina Faso. Le Vespère, 5, 357-369.

[18] Ministère de l'Environnement et du Développement Durable/Secrétariat Permanent du Conseil National pour l'Environnement et le Développement Durable (SP/ CONEDD) (2014) Cinquième rapport national du Burkina Faso à la conférence des parties à la convention sur la diversité biologique, Ouagadougou, $114 \mathrm{p}$.

[19] Ouédraogo, I., Sembene, M. and Dakouo, D. (2017) Inventory, Geographical Distribution of Caryedon Species in Burkina Faso, and Evaluation of Their Impact on Stored Groundnut. Advances in Entomology, 5, 55-67. https://doi.org/10.4236/ae.2017.52005

[20] Guinko, S. (1985) Contribution à l'étude de la végétation et de la flore du Burkina Faso (ex Haute-Volta). Origine botanique de quelques outils et objets artisanaux en bois. Journal d'Agriculture Traditionnelle et de Botanique Appliquée, 32, 235-239. https://doi.org/10.3406/jatba.1985.3938

[21] Fontès, J. and Guinko, S. (1995) Carte de la végétation et de l'occupation du sol du 
Burkina Faso. Notice explicative. Ministere de la Cooperation Franfaise, Projet Campus (88 313 101). Université Paul Sabatier, Toulouse, 68 p.

[22] Ganaba, S. (2008) Caractérisation, utilisations, tests de restauration et gestion de la végétation ligneuse au Sahel, Burkina Faso. Ph.D. Dissertation, Université Cheich Anta Diop (UCAD), Dakar, 308 p.

[23] Hijmans, R.J., Cameron, S.E., Parra, J.L., Jones, G.P. and Jarvis, A. (2005) Very High Resolution Interpolated Climate Surfaces for Global Land Areas. International Journal of Climatology, 25, 1965-1978. https://doi.org/10.1002/joc.1276

[24] Hansen, M.C., DeFries, R.S., Townshend, J.R.G., Carroll, M., Dimiceli, C. and Sohlberg, R.A. (2003) Global Percent Tree Cover at a Spatial Resolution of 500 Meters: First Results of the MODIS Vegetation Continuous Fields Algorithm. Earth Interactions, 7, 1-15.

[25] Mayaux, P., Bartholome, E., Fritz, S. and Belward, A. (2004) A New Land Cover Map of Africa for the Year 2000. Journal of Biogeography, 31, 861-877.

https://doi.org/10.1111/j.1365-2699.2004.01073.x

[26] Farr, T.G., Rosen, P.A., Caro, E., Crippen, R., Duren, R., Hensley, S., Kobrick, M., Paller, M., Rodriguez, E., Roth, L., Seal, D., Shaffer, S., Shimada, J., Umland, J., Werner, M., Oskin, M., Burbank, D. and Alsdorf, D. (2007) The Shuttle Radar Topography Mission. Reviews of Geophysics, 45, 1-33, https://doi.org/10.1029/2005RG000183.1

[27] Araujo, M.B., Pearson, R.G., Thuiller, W. and Erhard, M. (2005) Validation of Species-Climate Impact Models under Climate Change. Global Change Biology, 11, 1504-1513. https://doi.org/10.1111/j.1365-2486.2005.01000.x

[28] Bernard, E. (2001) Vertical Stratification of Bat Communities in Primary Forests of Central Amazon, Brazil. Journal of Tropical Ecology, 17, 115-126. https://doi.org/10.1017/S0266467401001079

[29] Fahr, J. and Kalko, E.K.V. (2011) Biome Transitions as Centres of Diversity: Habitat Heterogeneity and Diversity Patterns of West African Bat Assemblages across Spatial Scales. Ecography, 34, 177-195. https://doi.org/10.1111/j.1600-0587.2010.05510.x

[30] Tews, J., Brose, U., Grimm, V., Tielbörger, K., Wichmann, M.C., Schwager, M. and Jeltsch, F. (2004) Animal Species Diversity Driven by Habitat Heterogeneity/Diversity: The Importance of Keystone Structures. Journal of Biogeography, 31, 79-92. https://doi.org/10.1046/j.0305-0270.2003.00994.x

[31] August, P.V. (1983) The Role of Habitat Complexity and Heterogeneity in Structuring Tropical Mammal Communities. Ecology, 64, 1495-1507. https://doi.org/10.2307/1937504

[32] Boussim, J. (2010) Les territoires phytogéographiques. 152-155. In: Thiombiano, A. and Kampmann, D. Eds., Atlas de la biodiversité de P Afrique de P Ouest, Tome II: Burkina Faso, Frankfurt University \& University of Ouagadougou, 625 p.

[33] Thiombiano, A. and Kampmann, D. (2010) Atlas de la Biodiversité de l'Afrique de l'Ouest Tome II. Burkina Faso, 625 p.

[34] Welbergen, J.A., Klose, S.M., Markus, N. and Eby, P. (2008) Climate Change and the Effects of Temperature Extremes on Australian Flying-Foxes. Proceedings of the Royal Society B, 275, 419-425. https://doi.org/10.1098/rspb.2007.1385

[35] Horàcek, I., Vladmir, H. and Gaisler, J. (2000) Bats of the Palearctic Region: A Taxonomic and Biogeographic Review. Proceedings of the VIIIth European Bats Research Symposium, Kraków, 23-27 August 1999, 11-157. http://www.muni.cz/research/publications/376871 
[36] Hawkins, B.A. Field, R., Cornell, H.V., Currie, D.J., Guégan, J.F., Kaufman, D.M., Kerr, J.T., Mittelbach, G.G., Oberdorff, T., O’brien, E.M., Porter, E.E. and Turner, J.R.G. (2003) Energy, Water, and Broad-Scale Geographic Patterns of Species Richness. Ecology, 84, 3105-3117.

[37] Kalko, E.K.V., Handley, C.O. and Handley, D. (1996) Organization, Diversity, and Long-Term Dynamics of a Neotropical Bat Community. In: Cody, M.L. and Smallwood, J.A., Eds., Long-Term Studies of Vertebrate Communities, Academic Publishing, Washington DC, 503-553.

[38] Kalko, E.K.V. (1997) Diversity in Tropical Bats. Tropical Biodiversity and Systematics. Proceedings of the International Symposium on Biodiversity and Systematics in Tropical Ecosystems, Bonn, 2-7 May 1994, 13-43.

[39] Kalko, E.K.V. (1998) Organisation and Diversity of Tropical Bat Communities through Space and Time. Zoology, 101, 281-297.

[40] Base Nationale de Données Topographiques (BNDT) (2012) Institut Géographique du Burkina. Burkina Faso.

[41] Sawadogo, W.J.D. (2019) Les chauves-souris de la ville de Ouagadougou: Diversité, distribution et risques sanitaires. Mémoire de Master, Université Joseph Ki-Zerbo, Département de Biologie et Physiologie Animales, Ouagadougou.

[42] Thiombiano, N.G., Boungou, M., Kangoyé, N.M., Kaleme, P.K., Sinaré, Y., Soubeiga, P., Sawadogo, J.D., Ouéda, A. and Kabré, G.B. (2021) Bats Diversity and Abundance, Record of Taphozous mauritianus E . Geoffroy St.-Hilaire, 1818 for the First Time in Burkina Faso. Journal of Entomology and Zoology Studies, 9, 26-31. 